\title{
Similarities and differences in the realized niche of two allopatric populations of a solitary bee under environmental variability
}

\author{
Nydia Vitale ${ }^{1}$, Juan Pablo Torretta ${ }^{3,4}$, Silvana Durante $^{5}$, Alicia Basilio ${ }^{6}$, \\ Diego Pedro VÁzQUEz ${ }^{1,2,4}$
}

\author{
${ }^{1}$ Instituto Argentino de Investigaciones de las Zonas Áridas, CONICET, Av. Ruiz Leal s/n, Mendoza, Argentina \\ ${ }^{2}$ Facultad de Ciencias Exactas y Naturales, Universidad Nacional de Cuyo, Mendoza, Argentina \\ ${ }^{3}$ Facultad de Agronomía, Cátedra de Botánica General, Universidad de Buenos Aires, Av. San Martín, 4453, Ciudad \\ Autanoma de Buenos Aires, Argentina \\ ${ }^{4}$ Consejo Nacional de Investigaciones Científicas y Técnicas, Mendoza, Argentina \\ ${ }^{5}$ División Entomología, Museo de La Plata, Paseo del Bosque s/n, B1900DNG, La Plata, Argentina \\ ${ }^{6}$ Universidad de Buenos Aires, Facultad de Agronomía, Cátedra de Avicultura, Cunicultura y Apicultura, Av. San Martín, \\ 4453, Ciudad Autonoma de Buenos Aires, Argentina
}

Received 11 April 2019 - Revised 8 November 2019 - Accepted 13 January 2020

\begin{abstract}
We studied the realized niche of two distant allopatric wool-carder bee populations (bee-plant interaction and reproductive biology in weather variability). In one population, we analyzed the direct and indirect effects of weather on bee-resource interactions. The two populations shared several niche characteristics but showed some differences. Anthidium vigintipunctatum is a specialist species, with plasticity to extend the individual niche pushed by resources availability and weather variability. In both regions, the bee's response to weather condition was similar (nesting rates and the reproductive success). Causal analysis indicated climate directly determines bee's reproductive success, and indirect resource availability effects are subtle. The immediate response to environmental conditions warms about $A$. vigintipunctatum sensitivity to expected changes in the regional climate which could be a negative pressure on bees' survival.
\end{abstract}

\section{Nesting ecology / Local bee-plant interaction / Solitary bee / Climate effects / Allopatric populations niche}

\section{INTRODUCTION}

Climate change is one of the major anthropogenic alterations currently imposed on ecosystems

Electronic supplementary material The online version of this article (https://doi.org/10.1007/s13592-020-00731-y) contains supplementary material, which is available to authorized users.

Corresponding author: N. Vitale,

nydiavitale@gmail.com

Silvana Durante is deceased. This paper is dedicated to his memory.

Manuscript editor: Klaus Hartfelder (e.g., Gitay et al. 2002; Walther et al. 2002; Parmesan 2006; Stocker 2014; Cayan et al. 2016). This new reality implies substantial uncertainty regarding the magnitude and nature of its impacts on the ecosystem (Schliep et al. 2008), and scientists have worked toward a new integrated approach to the problem to assess the impact on biodiversity and its vulnerability. The effects of climate change on biodiversity will depend on the characteristics of the species involved (Kudo et al. 2004), the micro-scale environmental conditions (Kudo and Hiro 2006), regional climatic conditions (Tryjanowski et al. 2009), and how species interactions are affected (Hegland et al. 2009). 
Sometimes, individuals of different species in a community are considered independent entities, which ignores the fact that they may depend on interactions with other conspecific and heterospecific individuals (Redfearn and Pimm 1987). For example, a great variety of responses has been observed particularly in bees when the biotic or abiotic environment changes (Klein et al. 2002; Steffan-Dewenter 2002; Steffan-Dewenter et al. 2002; Williams et al. 2010), which suggests that resources such as food and nesting sites contribute to regulating bee populations but that a large part of this variation depends on how the environment influences the availability of these resources due to the impact of environmental circumstances (Roulston and Goodell 2011). In addition, climate affects all components of the community simultaneously, so when studying an interaction (e.g., plant resources-bees), both partners (plants and bees) should be studied simultaneously. Thus, it may not suffice to analyze the direct effect of climate on bees: the direct effect of plants on bees, the direct effect of climate on plants, and the indirect effect of climate on bees mediated by changes in flower availability should also be considered.

Because climatic conditions vary in space, it is possible to observe different contemporaneous populations of a species exhibiting different responses to environmental variability. Therefore, it is relevant to ask whether the response of different populations to climatic variables also varies through space and time: Is the response of populations to climatic variables dissimilar in a distant geographical region? Our goal is to assess the differences in the realized niche between two allopatric solitary bee populations and to determine which niche dimension shows plastic responses to environmental variables. We describe the local niche of a solitary bee species and assess whether it responds to climate variables similarly in two different regions to identify differences between populations that denote plastic phenotypic characteristics. Because we focus on one species of solitary bee we expect that both populations of this species, distant geographically, share several niche characteristics without being identical (Wiens et al., 2010). The inter-annual variability in temperature and precipitation could trigger similar, but not exactly equal, responses to environmental variability.

Here we study the ecology of a solitary bee to assess potential effects of floral resources and environmental variability on bee populations. We expect nesting behavior and larval food supply to vary geographically according to resource availability imposed by environmental variability. Moreover, in one population, we evaluate the direct and indirect effects of climate and floral resources in determining the nesting behavior of our study species. We expect that climate affects both bees and floral resources directly but that the indirect effect of climate on bees via floral resources determines bee nesting behavior.

To address these questions, we studied for 2 years populations of the solitary wool-carder bee Anthidium vigintipunctatum (Megachilidae) in two localities separated by more than $700 \mathrm{~km}$ (La Pampa and Mendoza, Argentina). We assessed the similarities and differences between populations in the realized niche. Using data on temperature and precipitation, we also assessed the response of our studied species to interannual whether condition throughout 2 years. In addition, in one locality (Mendoza), we analyzed the direct and indirect effects of weather on the interaction between this bee species and its main floral resource (pollen for larvae) throughout 9 years.

\section{MATERIALS AND METHODS}

\subsection{Species studied}

Our focal species was Anthidium vigintipunctatum Friese, a solitary bee native to xeric regions of north- and mid-western Argentina (Gonzalez and Griswold 2013; Fig. 1a). Bees in the genus Anthidium are commonly known as wool-carder bees because some species make cotton-like brood cells from plant hairs (trichomes; Michener 2007). Anthidium is among the most diverse genera of Megachilidae, comprising more than 180 species grouped into six subgenera occurring in all major regions of the world (Michener 2007). At least in the western desert of Argentine, species of Anthidium nest in preexisting cavities in wood, nested once a year 


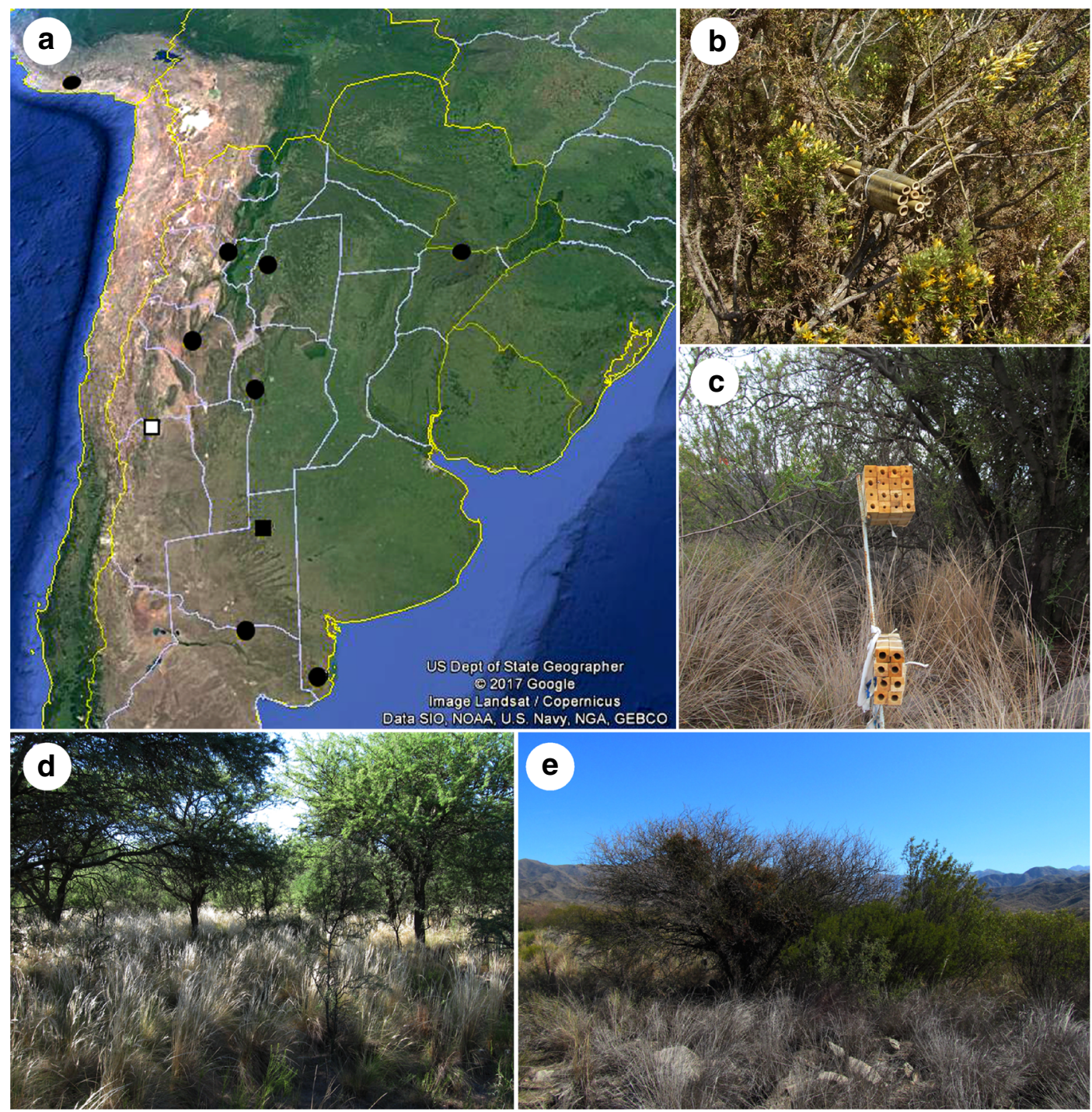

Figure 1. Natural history of A. vigintipunctatum. a Geographic bee distribution and study localities (La Pampa in black and Mendoza in white); previous records (circles) and new record (squares). Satellite image by Google Earth. Previous record from Gbif data base (https://www.gbif.org) and Discoverlife (http://www.discoverlife.org). b Bamboo canes traps-nest used in La Pampa. c wood pieces traps-nest used in Mendoza. d La Pampa landscape. e Mendoza landscape.

and are likely univoltine, except for $A$. andinum which nests twice a year and is likely bivoltine (Vitale et al. 2017).

\subsection{Study localities and field methods}

Data included here come from research projects conducted independently from each other in the two study localities. For this reason, the study design varies between localities. One dataset, collected in 2009-2011, comes from Anquilóo, Toay, La Pampa Province, Argentina (hereafter La Pampa). The dominant vegetation is a xeric "Caldenal" forest, an open forest forming an ecotone between the Pampean grassland to the east and the Monte to the west (Fig. 1a and d). 
Livestock raising is the main economic activity of the region (details in Torretta et al. 2014). The other dataset was collected in 2006-2013 in the Monte Desert of Villavicencio Nature Reserve, Mendoza Province, Argentina (hereafter Mendoza; Fig. 1a and e). We worked at two nearby sites at similar elevations and little disturbed by human activities (details in Vitale and Vázquez 2017 and Vitale et al. 2017).

The nesting ecology of bees was studied using trap nests: bamboo cane in La Pampa (Fig. 1b) and wooden in Mendoza (Fig. 1c) during two consecutive seasons (2009 and 2010). In La Pampa, 140 trap nests were placed in 2009 and 280 in 2010; in Mendoza, 288 traps were placed each study year (Table I; see further details in Torretta et al. 2014; Vitale and Vázquez 2017 and Vitale et al. 2017). The localities were visited monthly (La Pampa) or weekly (Mendoza) throughout the entire bee nesting and flowering season (austral spring and summer) to collect occupied trap nests. Additionally, in Mendoza, we conducted weekly floral surveys to estimate floral resources abundance (Vitale 2017).

\subsection{Laboratory methods}

Once nests had been built, they were taken to the laboratory and kept at room ambient conditions until adult emergence. For each nest, we recorded the number of brood cells, the number of emerged adults, the emergence date, and the identity and number of parasitic species (parasites and/or cleptoparasites). The voucher specimens from this study were deposited at the entomological collections of Cátedra de Botánica General, Facultad de Agronomía, Universidad de Buenos Aires; Museo de La Plata, Universidad Nacional de La Plata; Museo Argentino de Ciencias Naturales "Bernardino Rivadavia," CONICET; and Instituto Argentino de Investigaciones de las Zonas Áridas, CONICET.

We extracted pollen samples from brood cells (La Pampa: $n=40$, two per nest, and Mendoza: $n=46$, one per nest) for taxonomic identification. Pollen identification was conducted with the socalled natural method without acetolyzation (Louveaux et al. 1978; Maurizio et al. 1978), using light microscopy and comparison with a reference collection. The latter included all flowering plant species recorded in both study plots.

\subsection{Data analyses}

All statistical analyses were performed with $\mathrm{R}$ statistical software, version 3.2.0 (R Core Team 2015). Plots were drawn with R's ggplot 2 package version 0.9.3.1 (Wickham 2009).

We used the nest data to calculate the reproductive success (as number of emerged host adults/number of brood cells) and, because the

Table I. Details of samples method by study area and year

\begin{tabular}{|c|c|c|c|c|c|c|c|}
\hline Year & Region & $\begin{array}{l}\text { Area per } \\
\text { locality (m) }\end{array}$ & $\begin{array}{l}\text { Trap nests } \\
\text { initial per } \\
\text { locality }\end{array}$ & $\begin{array}{l}\text { Nest } \\
\text { built }\end{array}$ & $\begin{array}{l}\text { Occupancy } \\
\text { rate }\end{array}$ & $\begin{array}{l}\text { Trap nests hole size } \\
\text { (long } \mathrm{cm} \times \text { diameter } \\
\mathrm{cm} \text { ) }\end{array}$ & $\begin{array}{c}\text { Plant } \\
\text { survey } \\
\text { area }\left(\mathrm{m}^{2}\right)\end{array}$ \\
\hline \multirow[t]{2}{*}{2009} & La Pampa & $\begin{array}{l}2 \text { transects } \\
\text { (intervals of } \\
50-100 \mathrm{~m} \text { ) }\end{array}$ & 140 & 39 & 0.28 & $\begin{array}{l}\text { Variable } \\
\quad \text { (range } x \text { to } x \text { ) }\end{array}$ & $\begin{array}{l}\text { No } \\
\text { survey }\end{array}$ \\
\hline & Mendoza & $200 \times 100$ & 288 & 52 & 0.18 & $\begin{array}{l}14 \mathrm{~cm} \times 0.5 \mathrm{~cm} \\
14 \mathrm{~cm} \times 0.8 \mathrm{~cm} \\
28 \mathrm{~cm} \times 1.1 \mathrm{~cm}\end{array}$ & 1680 \\
\hline \multirow[t]{2}{*}{2010} & La Pampa & $\begin{array}{l}4 \text { transects } \\
\text { (intervals of } \\
50-100 \mathrm{~m} \text { ) }\end{array}$ & 280 & 30 & 0.10 & $\begin{array}{l}\text { Variable (range } x \\
\text { to } x \text { ) }\end{array}$ & $\begin{array}{l}\text { No } \\
\text { survey }\end{array}$ \\
\hline & Mendoza & $200 \times 100$ & 288 & 4 & 0.01 & $\begin{array}{l}14 \mathrm{~cm} \times 0.5 \mathrm{~cm} \\
14 \mathrm{~cm} \times 0.8 \mathrm{~cm} \\
28 \mathrm{~cm} \times 1.1 \mathrm{~cm}\end{array}$ & 1680 \\
\hline
\end{tabular}


number of trap nests placed in both localities and years was different, we calculated occupancy rate (as number nests built / trap nests placed). To evaluate potential differences between the realized niches of both populations we compared four variables using Student's $t$ test (t.test function $\mathrm{R}$ stats) from a total 125 nests from both localities and the two studied seasons. Response variables were number of brood cells per nest, number of emerged adults per nest, reproductive success, and number of emerged parasites or cleptoparasites per nest.

To assess potential differences between populations in the degree of generalization/ specialization in larval food supply, we used the generalist/specialist $D$ index to estimate the width of the population niche. This index is calculated as $D=1-\left(1 / \sum q_{j}^{2}\right)$ where $q_{j}$ is the proportion of the resource $j$ in the population's diet (Levins 1968). It indicates specialization when $1<D<2$, moderate specialization when $2<D<3$, and generalization when $D>3$. We also quantified individual and population level specialization for pollen uses with the WTdMC function of the RInSp package of R statistical software (Zaccarelli et al., 2013). We analyzed the total niche width (TNW, Roughgarden 1974), the within individual component (WIC), and the rate WIC/TNW (proportion of TNW explained by within individual variation; Sargeant 2007). WIC/TNW approaches 1 when all individuals use the full range of the population's niche, whereas smaller values indicate decreasing inter-individual overlap and hence greater individual specialization.

To compare the environmental climatic conditions of both study localities, statistical and graphical representations of the climate were generated from the database of the National Meteorological Service of Argentina (SMN, for detailed methodology and results see in ESM1: Characterization of the climate in both regions). We explored as interest variables daily average temperature, minimum and maximum daily temperature, and total and maximum daily precipitation. Each climatic variable used was averaged in each day (1-365) for the years recorded. To assess whether the environmental conditions of both localities are equivalent, a graphic representation of the climate (average daily temperature, minimum and maximum daily temperature) was generated with all historical data; the smoothed curve was constructed with a local polynomial regression fitting (Wickham 2009). Finally, the linear adjustment (GLM) of each daily temperature variable was evaluated between localities (all temperature variables adjusted to parametric analysis requirements). For precipitation variables, we used noparametric analyses (Wilcoxon test) to asses differences between regions.

To evaluate whether the number of nest built differed between study localities or years (2009-2010), we used a $\chi^{2}$ test with function chisq.test of the stats package of R; as data did not meet the assumptions of the test, we calculated statistical significance by simulation, using the option simulate.p.value = TRUE of function chisq.test. To assess the effect of inter-annual (9 years studied, 2006-2014) environment variability in Mendoza on bee reproductive output at population level (estimated as the sum of cells built in all nests in a given year), we used the d-separation test for causal models (Shipley 2013; for detailed methodology and results see in ESM2: Climate-resources-bee relationship in Mendoza); where the mediating variable used to analyze the direct effect of climate was the number of nests built (total population of nests = defined as the total number of nest-traps occupied by site). We selected climatic variables from a set of temperature and precipitation data in Mendoza (SMN database). We constructed 30 climatic variables calculated from SMN database for the 9 years studied, 11 variables BIOCLIM (Hijmans et al. 2005) and 11 combinations of cumulative precipitation data associated with bee and plant behavior (Table S2.I). All climatic variables were standardized by subtracting the mean and dividing by the standard deviation. Biological variables were defined for bees as total built nests and total built cells; these variables were standardized in the same way as the climatic variables. For the resource, we defined flower anomaly as the number of flower (or inflorescences) of a given year divided by the historical average number of flowers (or inflorescences). 


\section{RESULTS}

We present a summary of our questions, comparisons, and main results (Table II), indicating figures and tables where each topic is illustrated.

\subsection{Nesting ecology}

A total of sixty-nine nests of A. vigintipunctatum were obtained from La Pampa ( $n=39$ in 2009 and $n=30$ in 2010) and fiftysix ( $n=52$ in 2009 and $n=4$ in 2010) from Mendoza (Table I). Anthidium vigintipunctatum nested in pre-existing cavities in our trap nests and lined each cell with plant fibers, exhibiting the typical wool-carder behavior of the genus. The number of nests built was significantly related to the locality and year of study $\left(\chi^{2}=20.61, \mathrm{df}=1\right.$, $P=0.0005)$. In La Pampa, the total number of cells, the number of adults emerged, the reproductive success (number of adults emerged/number of cells), and the occupancy rate (number nests built/ trap nest placed) were greater than in Mendoza during both study years (Fig. 2a-d). The four variables were also greater in 2009 than in 2010 in both localities (Table III; Fig. 2). However, the notorious decrease in all analyzed variables during the second season homogenizes both populations and the differences were not significant (Table III). Reproductive success (number of emerged adults/number of cells per nest) was not significantly different in any of the localities between years; the comparison between localities was only significant in 2009 (Table III).

Anthidium vigintipunctatum had two latency periods in both study localities and years (Fig. 3). Emergencies occurred after one overwinter (210 to 450 days from nest construction) or two overwinters (630 to 780 days from nesting). The peak of emergence occurred approximately at 300 days for La Pampa and 360 days for Mendoza or 660 days for La Pampa and 720 days for

Table II. Resume of questions, comparisons and main results

\begin{tabular}{|c|c|c|c|}
\hline Question & Locality & Comparison & Main results \\
\hline $\begin{array}{l}\text { Is the realized niche } \\
\text { equal for whole } \\
\text { species? }\end{array}$ & $\begin{array}{l}\text { La Pampa vs } \\
\text { Mendoza }\end{array}$ & $\begin{array}{r}\text { Realized niche } \\
(2009-2010)\end{array}$ & $\begin{array}{l}\text { Similarities: builds nests in pre-existing } \\
\text { cavities, cells lined with plant trichomes. } \\
\text { Mostly univoltine cycle but some individuals } \\
\text { exhibiting parsivoltinism. Sects. } 3.1 \text { and } 4 \text {. } \\
\text { Differences: diapauses, diet, adult activity } \\
\text { and enemy association. Figures } 3,4 \text {, and } 5 \text {, } \\
\text { Sects. } 3.2 \text { and } 3.3\end{array}$ \\
\hline $\begin{array}{l}\text { Is the climatic condition } \\
\text { similar in a distant } \\
\text { geographical region? }\end{array}$ & $\begin{array}{l}\text { La Pampa vs } \\
\text { Mendoza }\end{array}$ & $\begin{array}{l}\text { Climatic conditions } \\
\quad(2009-2010)\end{array}$ & $\begin{array}{l}\text { Climate: Weather comparable localities. } \\
\text { ESM1: Characterization of the climate } \\
\text { in both regions and Sect. } 3.4\end{array}$ \\
\hline $\begin{array}{l}\text { Is the response of } \\
\text { populations to climatic } \\
\text { variables dissimilar in } \\
\text { a distant geographical } \\
\text { region? }\end{array}$ & $\begin{array}{l}\text { La Pampa vs } \\
\text { Mendoza }\end{array}$ & $\begin{array}{l}\text { Phenological response } \\
\quad(2009-2010)\end{array}$ & $\begin{array}{l}\text { In both regions the bee's response to weather } \\
\text { condition was similar, for example, the } \\
\text { nesting } \\
\text { rates and the reproductive success. } \\
\text { Sect. 3.1, Fig. 2, Tables III and IV }\end{array}$ \\
\hline $\begin{array}{l}\text { Nesting behavior } \\
\text { responds to } \\
\text { environmental } \\
\text { changes, } \\
\text { but, is this variation } \\
\text { driven by resources or } \\
\text { just by climate? }\end{array}$ & Mendoza & $\begin{array}{l}\text { Causal Model } \\
\quad(2006-2014)\end{array}$ & $\begin{array}{l}\text { Rainfall in nesting season and flowering } \\
\text { P. flexuosa has a negative effect on both } \\
\text { bees and flowers. In contrast, rising } \\
\text { temperature during nesting and flowering } \\
\text { time has a positive effect on bees and } \\
\text { flowers. The magnitude of the direct effect } \\
\text { of climate on the bee reproductive success } \\
\text { exceeds the magnitude of the indirect } \\
\text { effect, mediated by the resource. } \\
\text { ESM2: Climate-resources-bee relationship } \\
\text { in Mendoza and Sect. } 3.5\end{array}$ \\
\hline
\end{tabular}


a
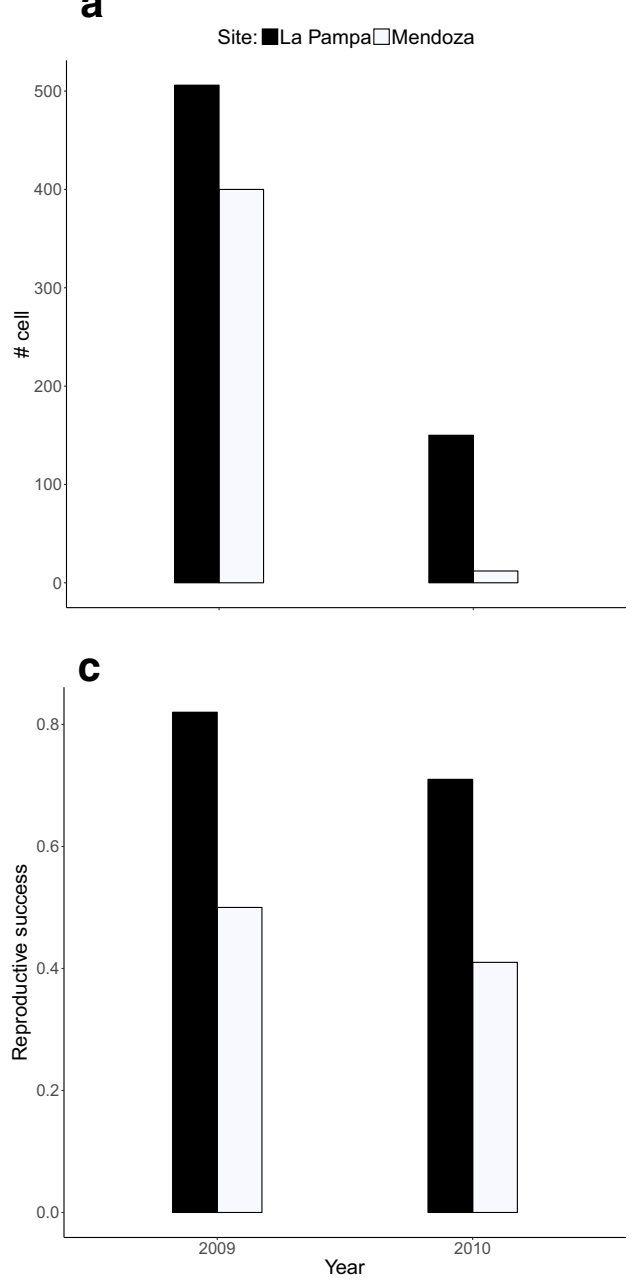

b
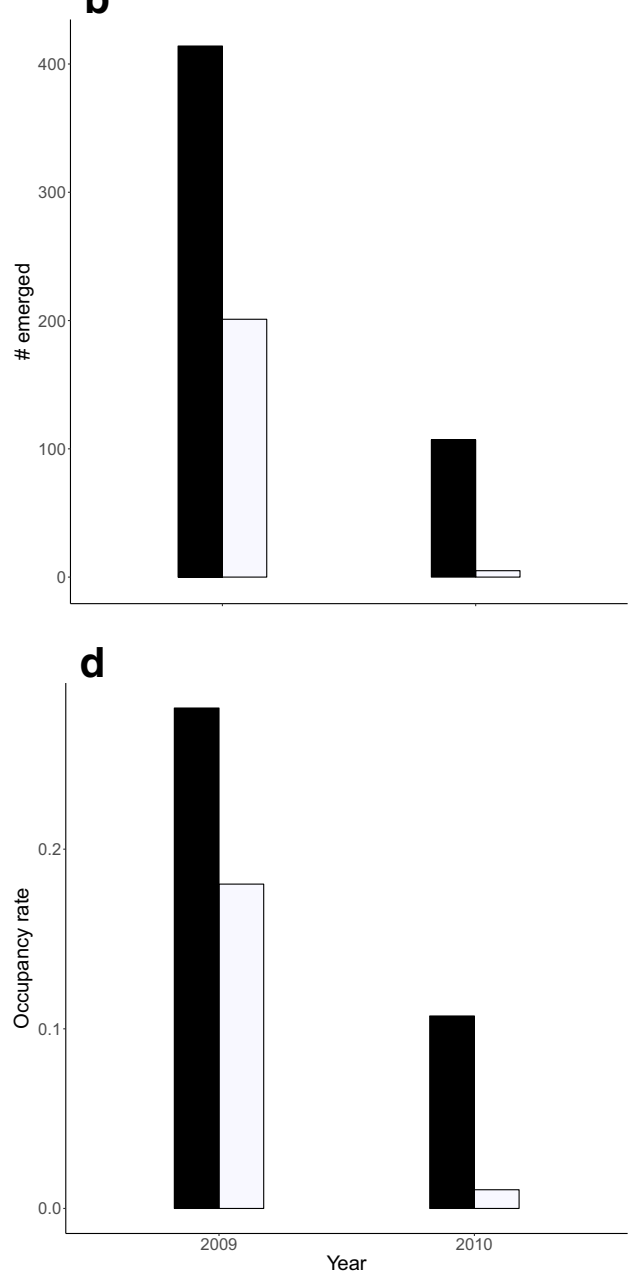

Figure 2. A. vigintipunctatum nesting behavior in both localities (site) and years studied. a Total cells built. b Total of emerged adults. c Reproductive success (number of emerged adults / number of cells built). d Occupancy rate (nests built/trap nest placed).

Mendoza when there was a double overwinter (Fig. 3). The population of Mendoza also showed in 2010 one individual which broke diapause without overwinter (47 days after the construction of the nest). Although there was inter-annual variability in the duration of diapause, we observed that latency was shorter in La Pampa.

\subsection{Natural enemies}

Nests were attacked by natural enemies in both study localities and years. In the population of La Pampa, nests were attacked only by parasites (wasps and one beetle), while in Mendoza nests were attacked by parasites and by predators (ants and Diptera larvae; see details in Vitale et al. 2017). Parasite diversity was greater in La Pampa than Mendoza (Fig. 4). Also, the number of attacks was greater in La Pampa than Mendoza in the two study years (Table IV). The rate of attacked cells was similar between localities (0.026 and 0.022 in La Pampa and Mendoza, respectively), and during 2010, the impact was greater 
Table III. Biological traits per nest of the nesting behavior of A. vigintipunctatum in both localities and years studied. Values in italics indicate significant differences $(\alpha=0.05)$

\begin{tabular}{|c|c|c|c|c|c|c|}
\hline Variable (per nest) & Region & $t$ & df & $p$ & $\mu_{1}( \pm s d)^{* 2009}$ & $\mu_{2}( \pm s d)^{* * 2010}$ \\
\hline \multirow[t]{2}{*}{ Cell built } & La Pampa & 7.34 & 58.8 & $<0.001$ & $12.9(5.51)$ & $5.25(3.08)$ \\
\hline & Mendoza & 3.22 & 3.61 & 0.037 & $7.62(2.96)$ & $3.25(2.62)$ \\
\hline \multirow[t]{2}{*}{ Adults emerged } & La Pampa & 6.16 & 58.2 & $<0.001$ & $10.6(5.82)$ & $3.84(3.08)$ \\
\hline & Mendoza & 3.75 & 4.51 & 0.01 & $3.86(2.17)$ & $1.25(1.26)$ \\
\hline \multirow[t]{2}{*}{ Reproductive success } & La Pampa & 1.48 & 56.4 & 0.14 & $0.79(0.25)$ & $0.69(0.32)$ \\
\hline & Mendoza & 0.37 & 3.18 & 0.73 & $0.51(0.26)$ & $0.44(0.42)$ \\
\hline \multirow[t]{3}{*}{ Parasites } & La Pampa & 0.21 & 61.8 & 0.83 & $0.45(1.10)$ & $0.39(1.20)$ \\
\hline & Mendoza & -1.6 & 3.02 & 0.19 & $0.02(0.13)$ & $0.50(0.57)$ \\
\hline & Season & & & & $\mu_{1}( \pm \mathrm{sd})^{* \mathrm{LP}}$ & $\mu_{2}( \pm s d)^{* M}$ \\
\hline \multirow[t]{2}{*}{ Cell built } & 2009 & 5.37 & 52.5 & $<0.001$ & $12.9(5.51)$ & $7.69(2.96)$ \\
\hline & 2010 & 1.41 & 4.14 & 0.23 & $5.26(3.08)$ & $3.25(2.63)$ \\
\hline \multirow[t]{2}{*}{ Adults emerged } & 2009 & 6.77 & 44.5 & $<0.001$ & $10.6(5.82)$ & $3.86(2.17)$ \\
\hline & 2010 & 3.09 & 8.89 & 0.01 & $3.84(3.08)$ & $1.25(1.25)$ \\
\hline \multirow[t]{2}{*}{ Reproductive success } & 2009 & 5.02 & 80.6 & $<0.001$ & $0.79(0.25)$ & $0.52(0.26)$ \\
\hline & 2010 & 1.14 & 3.47 & 0.32 & $0.69(0.32)$ & $0.33(0.42)$ \\
\hline \multirow[t]{2}{*}{ Parasites } & 2009 & 2.37 & 37.8 & 0.02 & $0.44(1.11)$ & $0.01(0.13)$ \\
\hline & 2010 & -0.3 & 7.07 & 0.76 & $0.38(1.20)$ & $0.50(0.58)$ \\
\hline
\end{tabular}

than 2009 (0.08 and 0.15 in La Pampa and Mendoza, respectively).

\subsection{Larval food}

The population diet was broader in Mendoza than in La Pampa (12 and 1 plant species respectively). The individuals of La Pampa exclusively used pollen of Prosopis caldenia (Fabaceae; Fig. 5), and, although the diet in Mendoza was more diverse (Fig. 5), Prosopis flexuosa was by far the most common species in nest pollen provisions: it was found in $83 \%$ of samples, while in $52 \%$ of nests observed, it represented over $50 \%$ of pollen loads. Furthermore, $44 \%$ nests in Mendoza were far more specialized, with $P$. flexuosa representing 90$100 \%$ of pollen loads. In contrast, some nests (17\%) had no P. flexuosa pollen; brood cells in these nests were composed by pollen of Larrea spp. (Zygophyllaceae, five cells), Lycium chilense (Solanaceae, two cells) and, in one sample, a more diverse array of species (Pyrrhocactus sp.: Opuntiaceae; Larrea spp. and Lycium chilense). In addition to $P$. flexuosa, nests with mixed pollen sources usually included pollen of Larrea spp., Lycium chilense, Capparis atamisquea (Capparaceae), and the exotic Spartium junceum (Fabaceae); other rarely occurring species included Hoffmannseggia eremophila and Zuccagnia punctata (Fabacaeae), Echinopsis leucantha (Opuntiaceae), Erodium cicutarium (Geraniaceae), Phacelia artemisioides (Boraginaceae) and Schinus aff. Fasciculata (Anacardiaceae). The generalization index $D$ was thus higher in Mendoza $(D=2.85)$ than in La Pampa $(D=1)$.

In spite of greater breadth of pollen use in nests in Mendoza than in La Pampa, total niche width was relatively low $(\mathrm{TNW}=1.32)$; the overlap in pollen composition among individual diets was $\mathrm{WIC} / \mathrm{TNW}=0.34$, indicating only moderate overlap in individual diets (WIC/ $\mathrm{TNW}=0$, no overlap vs. $\mathrm{WIC} / \mathrm{TNW}=1$, total overlap). Furthermore, the nesting activity period of $A$. vigintipunctatum always fell within the flowering period of P. flexuosa (Fig. 6). 

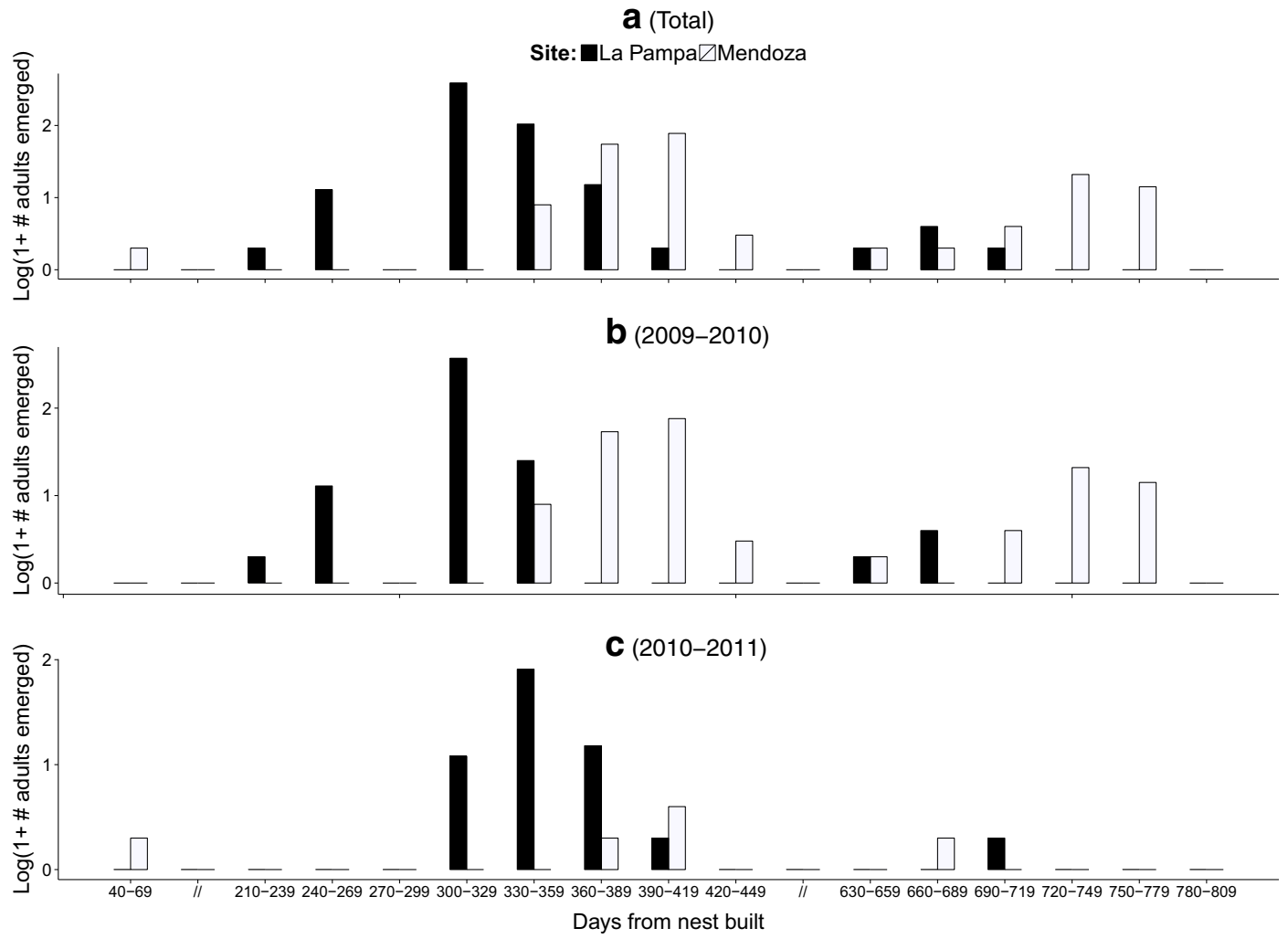

Figure 3. Patterns of emergence of A. vigintipunctatum in both localities (site) and years studied.

Site: La Pampa $\triangle$ Mendoza

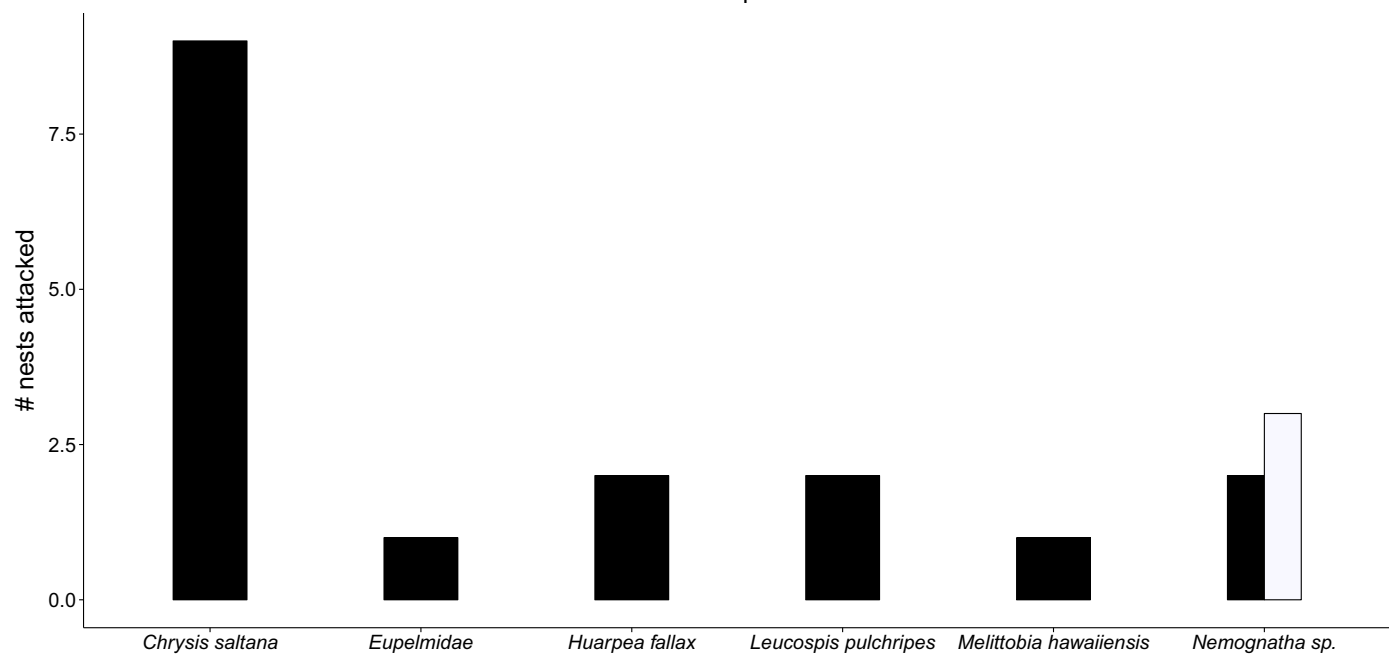

Figure 4. Natural enemies' attacks. Number of nest of A. vigintipunctatum attacked by parasites in both localities (site) and years studied. 
Table IV. Attacks of natural enemies in both localities and years studied

\begin{tabular}{lllllll}
\hline Year & Region & Nests built & Nests attacked & Cell built (total) & Cell attacked & Effect on larval mortality \\
\hline 2009 & La Pampa & 39 & 9 & 506 & 13 & 0.026 \\
& Mendoza & 52 & 3 & 400 & 9 & 0.022 \\
2010 & La Pampa & 30 & 5 & 150 & 12 & 0.15 \\
& Mendoza & 4 & 2 & 13 & 2 & 0.08 \\
\hline
\end{tabular}

\subsection{Climate in the two regions}

The two study localities lie within the Arid Diagonal of Argentina and are climatically comparable (Burkart et al. 1999), in spite of being separated by more than $700 \mathrm{~km}$ (Fig. 1 and details in ESM1). The historical temperature regime observed is equivalent in both localities, although Mendoza is warmer and drier, with precipitation occurring mostly during the summer, albeit with high variability. La Pampa presents more frequency of precipitation episodes through the year than Mendoza (ESM1: Figs. S1.1-2).

Weather conditions varied markedly between the two study years. Spring 2009 was cooler and drier than the historical record. In contrast, climatic conditions in 2010 were different in the two study localities (ESM1: Figs. S1.3-4). Whereas in La Pampa temperature was comparable to the historical average, in Mendoza, maximum temperature was anomalously high, with upperend extremes in winter and spring (ESM1: Fig. S1.3). Precipitation in 2010 was low in the spring and high in the summer in La Pampa, with the reverse pattern in Mendoza (ESM1: Fig. S1.4).

\subsection{Climate-resources-bee relationship in Mendoza}

Our path analysis models indicated that climate has a direct and indirect effect on bees and floral resources (details in ESM2). The d-separation test showed that rainfall in October, November, and December (nesting season) and September, October, and November (flowering P. flexuosa) has a negative effect on both bees and flowers (Fig. S2.2 and Table S2.II). In contrast, rising temperature during the wettest period (coincident with nesting and flowering) has a positive effect on bees and flowers. The magnitude of the direct

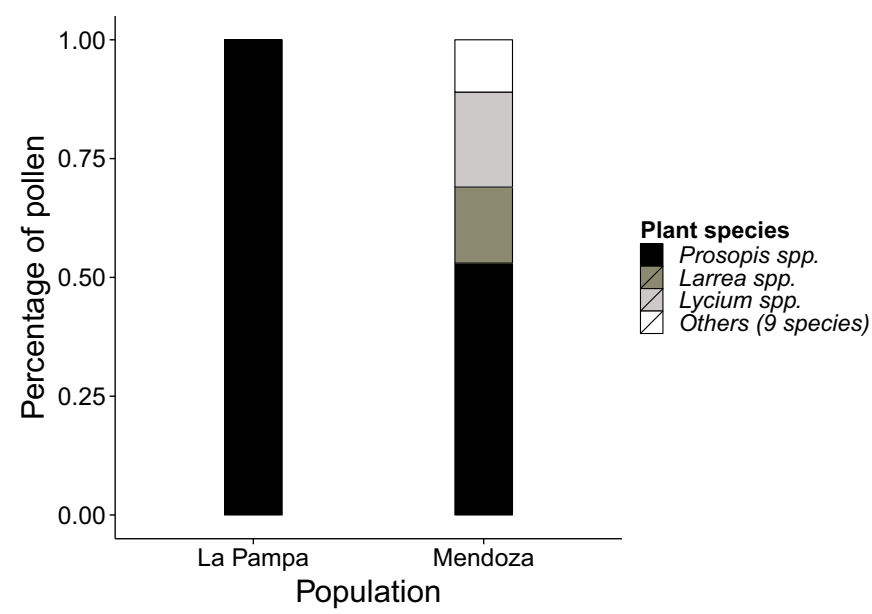

Figure 5. Pollen provision masses in cells analyzed. Proportional used of plant species in both localities in 2009 by A. vigintipunctatum. 


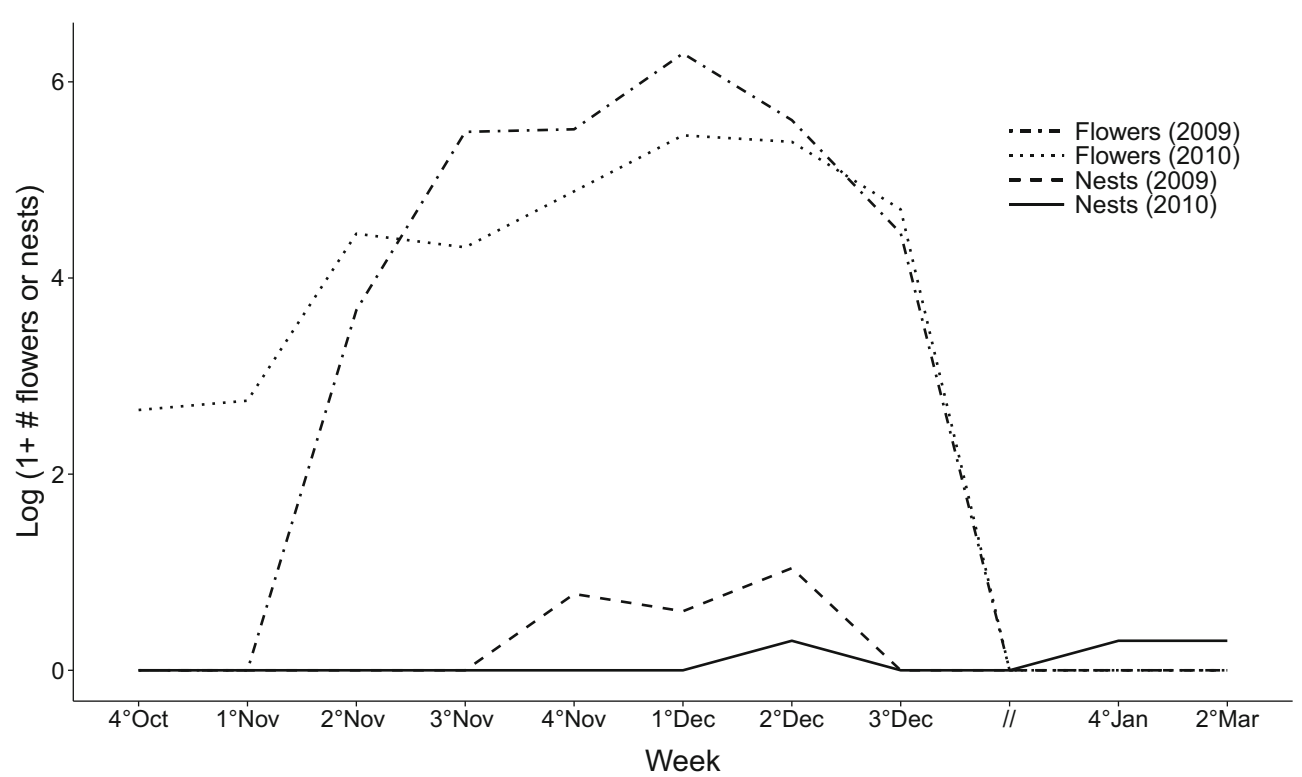

Figure 6. Phenological temporal overlap A. vigintipunctatum and P. flexuosa in Mendoza.

effect of climate on the reproductive success of A. vigintipunctatum exceeds the magnitude of the indirect effect, mediated by the resource (Table S2.III).

\section{DISCUSSION}

Our conceptual starting points to try understand the climate change-bees relationship were the four steps proposed by several authors to describe climate change-biodiversity relationship in the early century XXI (Kudo et al. 2004; Kudo and Hiro 2006; Tryjanowski et al. 2009; Hegland et al. 2009): the characteristics of the species involved, the micro-scale environmental conditions, the regional climatic conditions, and how species interactions are affected.

Our study indicates that allopatric populations of Anthidium vigintipunctatum are ecologically similar in several ways, as we expected. In agreement with the findings from previous studies on Anthidium species (e.g. Michener 2007; Gonzalez and Griswold 2013; Vitale et al. 2017), A. vigintipunctatum builds nests in pre-existing cavities in canes or wood, with cells lined with plant trichomes, which has a mostly univoltine cycle but some individuals exhibiting parsivoltinism (small proportion of individuals of an age cohort require an additional year or more to complete development to the adult stage; Torchio and Tepedino 1982). Yet, we also observed differences in the natural history (diapauses, diet, adult activity and enemy association) among the two localities. The greater duration of the diapause in Mendoza than in La Pampa could be explained by a delay in emergence so that the new individuals find favorable environmental conditions. However, it is important to note that in all cases, diapause and emergence were completed under laboratory conditions, which are arguably less variable and less extreme than observed field conditions. In Mendoza, the period of nest construction overlapped with the flowering period of $P$. flexuosa, its main pollen source. This shrub is a versatile resource (abundant, with broad phenological period and offering two type of reward) providing pollen and nectar with little variation in flowering time between years (N. Vitale, unpubl. data). Phenological overlap with plant resources was also observed for another specialist bee species in our study area in Mendoza: the wood-boring bee Trichothurgus laticeps and its main resource Opuntia sulphurea (Vitale and Vázquez 2017). Apparently, the end of diapause 
observed in La Pampa also allows the temporal overlap of the adults of A. vigintipunctatum and the maximum availability of flowers of P. caldenia (J.P. Torretta, unpubl. data).

The degree of specialization in larval pollen supply differed moderately among study localities. Anthidium vigintipunctatum behaves as an extreme specialist in La Pampa, while it is only a moderate specialist population with specialized individuals in Mendoza. Optimal foraging patterns may explain facultative specialization observed, but at least in some native bees, foraging is far more plastic and extensive than previously believed and does not follow a simple optimal foraging strategy (Jha and Kremen 2013). Furthermore, sampling design also differed between localities, and such differences could partly explain the contrasting results: whereas trap nests in Mendoza were laid out in poles at regular distances (see Vitale and Vázquez 2017; Vitale et al. 2017), trap nests in La Pampa were laid out in forest patches of $P$. caldenia, with some traps hung from the branches of this tree species. Such a proximity to the abundant pollen source (J.P. Torretta, unpubl. data) may have biased the results, making it more likely that bees foraged in flowers of this species. It is known that solitary bees are very conservative in their dispersal; many populations maintain the same nesting localities for decades. In addition, maximum foraging distances of small solitary bees are estimated at 150-600 m (Gathmann and Tscharntke 2002). Thus, a reasonable interpretation of the monolecty observed in La Pampa is that it is a natural response to the proximity/abundance to flowers of $P$. caldenia, even if the species can use flowers from other plant species. This interpretation is reasonable based on findings from a previous study in the same study area in La Pampa (Marrero et al. 2014), in which A. vigintipunctatum was recorded visiting flowers of four plant species (not including $P$. caldenia).

In Mendoza, the spatial distribution of individuals of P. flexuosa is irregular and the proximity of the trap nests to the resource highly variable. Yet, $83 \%$ of all pollen samples analyzed contained pollen of $P$. flexuosa, although only $15 \%$ corresponded to monolectic samples. In Mendoza, A. vigintipunctatum uses pollen of $P$. flexuosa more frequently than pollen of other species; however, it also uses complementary resources. The presence of other pollen species in the brood pollen loads analyzed in Mendoza could be a response to the spatial-temporal availability of P. flexuosa and other resources. Aguiar et al. (2013) proposed that changes in the trophic niche may be the result of a combination of factors such as the existence of several levels of preference or fidelity of bees by a specific plant, spatial/temporal fluctuations in resource abundance, duration of flowering peak, and/or by the activity period of adult bees. Other species frequently used as pollen source were Larrea spp. In our study locality in Mendoza there are three species of Larrea and are dominant in the community. Pollen of Larrea as complementary resources could be due to a greater resource availability, but a detailed study is necessary to evaluate it.

Nests in La Pampa were attacked by a greater diversity of parasites than in Mendoza. Nests were attacked by the beetle Nemognatha sp. (Meloidae) in both localities and by Chrysis saltana Bohart (Chrysididae) and Leucospis pulchriceps Cameron (Leucospidae) in La Pampa and Chrysis striatula Bohart and Leucospis hopei Westwood in Mendoza (Vitale et al. 2017). Our results showed an interesting scenario to expand in further studies; we found the same pattern for two different interactions: mutualistic (bee-plant resources) and antagonistic (bee-parasite). In both interactions, both populations share close phylogenetic species, even the same genera (A. vigintipunctatum-Prosospis as the larval food source and A. vigintipunctatum-Chrysis and Leucospis as brood parasites). Is the pattern found an evolutionary mirror (resource or host conservatism)? Or on the contrary, does it show an ecological current process (abundance response)? How do we have to interpret our association bee-brood parasites (one host species and close parasites changed)?

In face of inter-annual weather variability, A. vigintipunctatum responded similarly in the two distant localities to the 2009-2010 climatic anomalies: the nesting behavior of both populations was affected by the environmental 
conditions of the year, although with different magnitudes. Reproductive success and occupancy rates decreased in both localities between 2009 and 2010 mirroring the notable weather anomaly characteristic of 2010 .

Nesting behavior responds to environmental changes, but, is this variation driven by resources or just by climate? Our results for Mendoza (causal model) indicate nesting behavior is affected by climate directly both negatively (precipitation) and positively (temperature) during the nesting period. The Mendoza population showed that the weather characteristics during nesting are critical in the reproductive success of the species with an immediate response (direct effect of climate on cells built by bees). There is a general consensus about the increase of the frequency and/or intensity of extreme events as a consequence of climate change (Easterling et al. 2000). Many biological processes undergo sudden changes in response to particular temperature or precipitation thresholds (Pisek et al. 1973; Parsons 1997). For example, periods of heavy rainfall can alter the breeding systems of various organisms (Easterling et al. 2000) and changes in the frequency of seasonal droughts or precipitation can induce physical or behavioral changes in some species and dramatic changes in the distribution of some other species (Parmesan et al., 2000). Our study highlights the potential sensitivity of A. vigintipunctatum to climate change consequences, since it would present an immediate response (change in reproductive events) to environmental conditions. In agreement with our observations in both localities in 2010, we recorded in Mendoza through 9 years (2006-2014) a negative effect on reproductive success in years with a greater anomaly of precipitation to the historical one. The anomaly of precipitation is an expected change in the future regional climate (Boninsegna 2014). For the foothill areas in Mendoza, where rainfall occurs during the summer in the form of convective storms, the summer precipitation has significantly increased in recent decades and it is coincident with nesting activity bloom and the negative response observed in Mendoza (decrease in reproductive success, lower number of nests and built cells). Boninsegna (2014), using model PRECIS (INPE) A2 climate change scenario, predicted several futures changes in precipitation and temperature, with the increase of summer storms in our study area and noticeably accentuated for the end of the current century. These projected changes could be a negative pressure on A. vigintipunctatum and compromise its future survival, at least in some populations.

The results of Mendoza's causal model also indicate that the nesting behavior responds to resource availability, but the effect seems subtler than weather. Many oligolectic (and some polilectic) bees use plant resources that are predictably abundant both in time and space and beyond the phenological overlapping with their resource do not present morphological or physiological adaptations associated with foraging behavior (Wcislo and Cane 1996), for example, it has been observed that the ability of specialist bees to remain in facultative diapause through years of scarce resources and emerge synchronously with flowering host plant in resource-rich years probably accounts for their ecological dominance and persistence (Minckley et al. 2000). The synchrony between flowering and bee phenology already was recorded in both studied localities, for example, Trichothurgus laticeps and Opuntia sulphurea (Vitale and Vázquez 2017) in Mendoza or Megachile catamarcensis Schrottky and P. caldenia (Torretta et al. 2014) in La Pampa. We interpret our results of cause-effect analysis in Mendoza population as indicating that A. vigintipunctatum specializes on $P$. flexuosa. This shrub blooms every year and although the variation in the number of flowers is remarkable (orders of magnitude, N. Vitale unpubl. data) even in "bad" years, the amount of floral resources may be enough to allow nesting. We propose that the predictability of flowering of the main resource moderates the impact of variability in abundance. We propose a similar pattern observed in T. laticeps and O. sulphurea: the presence of the wood-boring bee is determined by the presence of their host plant and the nesting is coupled to the flowering; however, the variation in the abundance of the resource does not influence the nesting behavior of the bee as a result of the versatility of the resource (Vitale and Vázquez 2017). Although A. vigintipunctatum is a specialist bee, it uses a broader pollen spectrum than T. laticeps. When P. flexuosa is available, the bee uses it preferentially, but when it is scarce, the individuals switch to other resources. Although we lack data of $P$. caldenia flowering for La Pampa, we 
propose for this area the same pattern observed in Mendoza; we expect this pattern because the study localities have large long-lived trees of $P$. caldenia which offer many of flowers every year in a predictable way.

Several new questions arise from the results of this work for Anthidium vigintipunctatum facing the expected climate change. How much of the impact of climate variability could be cushioned by the resource? Could a catastrophic response be triggered in the consumer population by exceeding the buffer capacity of the resource? Our work represents the first step; more studies are needed to assess the vulnerability of $A$. vigintipunctatum and other solitary bees in the context of climate change.

\section{GENERAL SUMMARY}

Climate change results from anthropogenic disturbances and may affect biodiversity depending on the characteristics of the species involved; the local-scale environmental conditions, the regional climatic conditions, and how species interactions are affected. We still do not know what environmental features best explains niche differences and whether climate or resources are main triggers of behavioral responses. We studied, in South America, two allopatric carder bee populations in terms of their similarities and differences in the realized niche, the characteristics of the local climate, the local bee-plant interaction, and reproductive bee response to inter-annual weather variability. In addition, in one population, we analyzed the direct and indirect effects of weather on bee-resource interactions during 9 years. We found that the two populations shared several niche characteristics (nesting and diapauses cycle), but with several subtler differences in their natural history (adult activity, diapauses date, diet). We observed Anthidium vigintipunctatum is a specialist species, with plasticity to extend the individual niche depending on the availability of resources and the environmental differences between regions. We observed that both regions are climatically equivalent and that the bee's response to inter-annual variability is similar in terms of occupancy rates and the reproductive success. Causal analysis in one of the study localities indicates that the climate determines the bee's reproductive success (immediate response) and that the effects of resource availability are subtler. Our study highlights the potential sensitivity of A. vigintipunctatum to climate change projected for study area because it would present an immediate response to environmental conditions. The expected changes in the regional climate by anthropogenic climate change could be a negative pressure on A. vigintipunctatum and compromise its future survival, at least in some populations.

\section{ACKNOWLEDGMENTS}

We thank to family Rúgolo de Agrasar for the permission to conduct this study in Ea. Anquilóo and Hugo J. Marrero for his help in the field. To Interatio Lab members, we thank Georgina Amico for the help in field and laboratory activities. The section on characterization of the climate in both regions was carried out with the help and supervision of Dr. Ricardo Villalba, CONICET IANIGLA - Laboratorio Dendrocronología e Historia Ambiental. We thank Dr. Natacha Chacoff, CONICET_- Instituto de Ecología Regional (IER) and anonymous reviewers for comments on the manuscript.

\section{FUNDING INFORMATION}

Agencia Nacional de Promoción Científica y Tecnológica (PICT 08-12504, 0851, 20805, 2010-2779) and Consejo Nacional de Investigaciones Científicas y Técnicas (PIP 6564 and 2781), Argentina. La Pampa field work was supported by Agencia Nacional de Promoción Científica y Tecnológica (PICT 08-12504 and 0851), Argentina. Mendoza research was funded through grants from CONICET-Consejo Nacional de Investigaciones Científicas y Técnicas (PIP 6564 and 2781) and Agencia Nacional de Promoción Científica y Tecnológica (PICT 20805 and 2010-2779).

Similitudes et différences dans la niche réalisée de deux populations allopatriques d'une abeille solitaire dans des environnements variés.

écologie de nidification / interaction abeille-plante locale / abeille solitaire / effets climatiques / niche de populations allopatriques. 


\begin{abstract}
Ähnlichkeiten und Unterschiede in der Einnischung von zwei allopatrischen Populationen einer Solitärbiene in unterschiedlichen Umwelten.
\end{abstract}

Nestökologie / lokale Wechselwirkung Biene-Pflanze / Solitärbiene / Klimaeffekte / Einnischung allopatrischer Populationen.

\section{REFERENCES}

Aguiar C.M., Santos G.M.d.M., Martins C.F., Presley S.J. (2013) Trophic niche breadth and niche overlap in a guild of flower-visiting bees in a Brazilian dry forest. Apidologie 44, 153-162

Boninsegna J.A. (2014) Impacto del cambio climático en los oasis del oeste argentino. Ciencia e investigación 64(1), 46-58

Burkart, R., Bárbaro, N. O., Sánchez, R. O., \& Gómez, D. A. (1999). Eco-regiones de la Argentina. Presidencia de la Nación-Secretaría de Recursos Naturales y Desarrollo Sustentable-Administración de Parques Nacionales.

Cayan, D. R., Dettinger, M. D., Pierce, D., Das, T., Knowles, N., Ralph, F. M., and Sumargo, E. 2016. Natural variability, anthropogenic climate change, and impacts on water availability and flood extremes in the Western United States. Water Policy and Planning in a Variable and Changing Climate, 17-42.

Easterling D.R., Meehl G.A., Parmesan C., Changnon S.A., Karl T.R., Mearns L.O. (2000) Climate extremes: observations, modeling, and impacts. Science 289, 20682074

Gathmann A., Tscharntke T. (2002) Foraging ranges of solitary bees. Journal of animal ecology 71(5), 757764

Gitay, H. Suárez, A. Watson, R. T. and Dokken, D. J. 2002. Climate change and biodiversity. IPCC Technical Paper V.

Gonzalez V.H., Griswold T.L. (2013) Wool carder bees of the genus Anthidium in the Western Hemisphere (Hymenoptera: Megachilidae): diversity, host plant associations, phylogeny, and biogeography. Zool. J. Linn. Soc. 168, 221-425

Hegland S.J., Nielsen A., Lázaro A., Bjerknes A.L., Totland Ø. (2009) How does climate warming affect plant-pollinator interactions? Ecology Letters 12(2), 184-195

Hijmans, R., S. Cameron, J. Parra, P. Jones, A. Jarvis, and K. Richardson. 2005. WorldClim - global climate data. Very High Resolution Interpolated Climate Surfaces for Global Land Areas.

Jha S., Kremen C. (2013) Resource diversity and landscape-level homogeneity drive native bee foraging.
Proceedings of the National Academy of Sciences 110(2), 555-558

Klein A.M., Steffan-Dewenter I., Buchori D., Tscharntke T. (2002) Effects of land-use intensity in tropical agroforestry systems on coffee flowervisiting and trap-nesting bees and wasps. Conservation biology 16, 1003-1014

Kudo G., Hiro A.S. (2006) Habitat-specific responses in the flowering phenology and seed set of alpine plants to climate variation: implications for global-change impacts.Population. Ecology 48(1), 49-58

Kudo G., Nishikawa Y., Kasagi T., Kosuge S. (2004) Does seed production of spring ephemerals decrease when spring comes early? Ecological Research 19(2), 255259

Levins R. (1968) Evolution in changing environments: some theoretical explorations. Princeton University Press

Louveaux J., Maurizio A., Vorwohl G. (1978) Methods of Melissopalynology. Bee World 59, 139-157

Marrero H.J., Torretta J.P., Medan D. (2014) Effect of land use intensification on specialization in plant-floral visitor interaction networks in the Pampas of Argentina. Agriculture, Ecosystems and Environment 188, 63-71

Maurizio J., Louveaux A., Vorwohl G. (1978) Les méthodes de la mélisso-palynologie. Apidologie 1, 211-227

Michener C.D. (2007) The bees of the world. Johns Hopkins University Press, Maryland

Minckley R.L., Cane J.H., Kervin L. (2000) Origins and ecological consequences of pollen specialization among desert bees. Proceedings of the Royal Society of London B: Biological Sciences 267, 265-271

Parmesan C., Root T.L., Willig M.R. (2000) Impacts of extreme weather and climate on terrestrial biota. Bulletin of the American Meteorological Society 81(3), 443-450

Parmesan C. (2006) Ecological and evolutionary responses to recent climate change. Annual Review of Ecology, Evolution, and Systematics 37, 637-669

Parsons P.A. (1997) Extreme environmental change and evolution. Cambridge University Press

Pisek, A., W. Larcher, A. Vegis, K. Napp-Zinn, H. Precht, J. Christophersen, and H. Hensel. 1973. Temperature and life.

R Core Team (2015). R: A language and environment for statistical computing. R Foundation for Statistical Computing, Vienna, Austria (2013). Supplementary Figure S, 2 .

Redfearn, A. and S. L. Pimm. 1987. Insect outbreaks and community structure. Insect Outbreaks:99-133.

Roughgarden J. (1974) Niche width: biogeographic patterns among Anolis lizard populations. American Naturalist 108, 429-442

Roulston T.H., Goodell K. (2011) The role of resources and risks in regulating wild bee populations. Annual review of entomology 56, 293-312 
Sargeant B.L. (2007) Individual foraging specialization: niche width versus niche overlap. Oikos 116, 14311437

Schliep R., Bertzky M., Hirschnitz M., Stoll-Kleemann S. (2008) Changing Climate in Protected Areas?: Risk Perception of Climate Change by Biosphere Reserve Managers. GAIA-Ecological Perspectives for Science and Society 17(1), 116-124

Shipley B. (2013) The AIC model selection method applied to path analytic models compared using ad-separation test. Ecology 94, 560-564

Steffan-Dewenter I. (2002) Landscape context affects trapnesting bees, wasps, and their natural enemies. Ecological Entomology 27, 631-637

Steffan-Dewenter I., Münzenberg U., Bürger C., Thies C., Tscharntke T. (2002) Scale-dependent effects of landscape context on three pollinator guilds. Ecology 83, 1421-1432

Stocker T. (2014) Climate change 2013: the physical science basis: Working Group I contribution to the Fifth assessment report of the Intergovernmental Panel on Climate Change. Cambridge University Press

Torchio P.F., Tepedino V.J. (1982) Parsivoltinism in three species of Osmia bees. Psyche: A Journal of Entomology 89(3-4), 221-238

Torretta J.P., Durante S.P., Basilio A.M. (2014) Nesting ecology of Megachile (Chrysosarus) catamarcensis Schrottky (Hymenoptera: Megachilidae), a Prosopisspecialist bee. Journal of Apicultural Research 53, 590-598

Tryjanowski P., Kosicki J.Z., Kuzniak S., Sparks T.H. (2009) Long-term changes and breeding success in relation to nesting structures used by the white stork, Ciconia ciconia. Annales Zoologici Fennici 46, 34-38

Vitale, N. 2017. Ecología comparativa de especies de Anthidium (Hymenoptera: Megachilidae, Anthidiini) del Monte de Villavicencio y su posible respuesta frente al cambio climático. Doctoral Thesis. PROBIOL UNCUYO.

Vitale N., Vázquez D.P. (2017) Ecology and nesting biology of the wood-boring bee Trichothurgus laticeps (Hymenoptera: Megachilidae) in a Monte desert reserve in mid-western Argentina. Apidologie 48, 31-40

Vitale N., Gonzalez V.H., Vázquez D.P. (2017) Nesting ecology of sympatric species of wool carder bees (Hymenoptera: Megachilidae: Anthidium) in South America. Journal of Apicultural Research 56(5), 497-509

Walther G.R., Post E., Convey P., Menzel A., Parmesan C., Beebee T.J. et al (2002) Ecological responses to recent climate change. Nature 416(6879), 389-395

Wcislo W.T., Cane J.H. (1996) Floral resource utilization by solitary bees (Hymenoptera: Apoidea) and exploitation of their stored foods by natural enemies. Annual review of entomology 41, 257-286

Wickham H. (2009) ggplot2: elegant graphics for data analysis. Springer-Verlag, New York

Wiens J.J., Ackerly D.D., Allen A.P., Anacker B.L., Buckley L.B., Cornell H.V. et al (2010) Niche conservatism as an emerging principle in ecology and conservation biology. Ecology letters 13(10), 1310-1324

Williams N.M., Crone E.E., T'ai H.R., Minckley R.L., Packer L., Potts S.G. (2010) Ecological and life-history traits predict bee species responses to environmental disturbances. Biological Conservation 143(10), 22802291

Zaccarelli N., Bolnick D.I., Mancinelli G. (2013) RI n S p: an $r$ package for the analysis of individual specialization in resource use. Methods in Ecology and Evolution 4(11), 1018-1023

Publisher's note Springer Nature remains neutral with regard to jurisdictional claims in published maps and institutional affiliations. 